\title{
HUBUNGAN ASUPAN PROTEIN DAN KADAR INTERLEUKIN-6 DENGAN KADAR HEMOGLOBIN PADA REMAJA PUTRI STATUS GIZI LEBIH
}

\author{
CORELATION OF PROTEIN INTAKE AND INTERLEUKIN-6 LEVEL WITH \\ HAEMOGLOBIN LEVEL IN OVERNUTRITION FEMALE ADOLESCENTS
}

\author{
Tri Agustina ${ }^{1}$, Dono Indarto ${ }^{2}$, Sugiarto $^{3}$ \\ ${ }^{1}$ Bagian Program Profesi Fakultas Kedokteran UMS \\ ${ }^{2}$ Bagian Laboratorium Fisiologi Fakultas Kedokteran UNS \\ ${ }^{3}$ Bagian Ilmu Penyakit Dalam RSDM Surakarta Fakultas Kedokteran UNS \\ Korespondensi: Tri Agustina. Email: ta190@ums.ac.id
}

\begin{abstract}
ABSTRAK
Status gizi lebih dan anemia merupakan gangguan gizi yang sering muncul pada remaja putri. Remaja putri berisiko tinggi terjadi gangguan gizi tersebut karena cenderung mengalami peningkatan kebutuhan zat gizi, pembatasan pola konsumsi dan penyimpangan pola konsumsi. Asupan protein yang tinggi akan diubah menjadi lemak dan disimpan menjadi jaringan adiposa. Pada status gizi lebih, inflamasi kronik terjadi di jaringan lemak dan terjadi peningkatan sekresi sitokin proinflamasi, seperti interleukin 6 (IL-6). Kadar IL-6 yang tinggi meningkatkan kadar hepsidin, yang dapat menurunkan kadar besi (Fe) dalam sirkulasi. Penelitian ini bertujuan menganalisis hubungan antara asupan protein dan kadar IL-6 dengan kadar hemoglobin (Hb) pada remaja putri status gizi lebih. Data asupan protein menggunakan metode food recall 24 jam dan SQ-FFQ (semi quantitativefood frequency questionare). Kadar IL-6 diukur dengan pemeriksaan ELISA. Kadar Hb diukur dengan metode cyanmethaemoglobin. Hasil penelitian ini menunjukkan bahwa asupan protein dan kadar IL-6 tidak berhubungan dengan kadar $\mathrm{Hb}(p=0,132)$ dan $(p=0,607)$. Penelitian selanjutnya diharapkan untuk menganalisis hubungan status gizi lebih pada remaja putri dengan kejadian anemia, seperti kadar hepsidin, globin dan feritin.
\end{abstract}

Kata kunci: Asupan Protein, Kadar IL-6, Kadar Hb, Remaja Putri, Status Gizi Lebih

\section{ABSTRACT}

Overnutritional status and anemia are nutritional disorders that often occur in female adolescents. Female adolescents are at high risk of nutritional disorders because they tend to experience an enhanchement nutritional needs, restrictions on consumption patterns and eating disorder. High protein intake will be converted into fat and stored into adipose tissue. In overnutrition adolescents, chronic inflammation occurs in fat tissue and also increasing proinflamation sitokin secretion, such as interleukin 6 (IL-6). High levels of IL-6 increases hepsidin levels, and decreases iron ( $\mathrm{Fe}$ ) level in circulation. This study aims to analyze the corelation of protein intake and IL-6 level with haemoglobin level in overnutrition female adolescents. Data of protein intake is taken through 24 hours food recall and SQ-FFQ (semi quantitative-food frequency questionare). IL-6 levels were measured by ELISA while Hb level is obtained thorugh cyanmethaemoglobin method. The results of this study there is no corelation between protein intake and IL-6 level toward Hb level $(p=0,132)$ and $(p=0,607)$. It is suggested for other researcher to analyze corelation between overnutrition state in female adolescents and anemia symptomps such as hepsidin, globin, and feritin level.

Keywords: Protein Intake, IL-6 Levels, Hemoglobin Levels, Adolescent Girls, Overnutritional Status

\section{PENDAHULUAN}

Remaja merupakan masa peralihan dari anak-anak menjadi dewasa yang ditandai dengan pertumbuhan yang sangat cepat (growth spurt) dan perkembangan (Ariyani, 2010; Soetjiningsih, 2007; Brown dan Judith, 2005).
Remaja mempunyai risiko tinggi untuk terjadi gangguan gizi karena pada usia remaja terjadi peningkatan kebutuhan zat gizi, sering membatasi konsumsi makan, pola konsumsinya sering menyimpang dari kaidah-kaidah ilmu gizi (Arisman, 2009). 
Gangguan gizi yang sering muncul pada remaja adalah status gizi lebih dan anemia (Franks et al., 2010). Kedua gangguan tersebut merupakan beban gizi ganda yang dialami oleh seorang remaja dan berdampak buruk terhadap kesehatan remaja serta menjadi masalah kesehatan baik di negara berkembang maupun negara maju (Franks et al., 2010; De Onis et al., 2010). Anemia yang juga berdampak pada perkembangan remaja, seperti kemampuan motorik dan tingkat kecerdasan. Pada akhirnya prestasi belajar dan konsentrasi belajar menurun, karena rendahnya kadar hemoglobin dan penurunan oksigensi pada susunan saraf pusat (Fretham et al., 2011).

Prevalensi status gizi lebih pada remaja dilaporkan meningkat dari 4,2\% tahun 1990 menjadi 6,7\% tahun 2010 dan diperkirakan menjadi 9,1\% tahun 2020 (De Onis et al, 2010). World Health Organization (WHO) melaporkan sekitar 1,4 milyar orang dewasa usia $>15$ tahun mengalami status gizi lebih (overweight dan obesitas), dengan prevalensi tertinggi masih di negara-negara maju, seperti Amerika maupun Eropa (62\% dan 26\% obesitas) (WHO, 2008). Di Asia Tenggara, angka overweight mencapai 14\% dan 3\% obesitas (WHO, 2008). Prevalensi status gizi lebih pada remaja di Indonesia usia 16-18 tahun secara nasional sebanyak 7,3\%, terdiri dari $5,7 \%$ overweight dan 1,6\% obesitas (Balitbang Kemenkes RI, 2013). Prevalensi anemia di kawasan Asia Tenggara pada anak usia sekolah (5-15 tahun) sebesar 13,6\% (WHO, 2008). Menurut data Riskesdas tahun 2013, prevalensi anemia di Indonesia yaitu $21,7 \%$, dengan proporsi $20,6 \%$ diperkotaan dan $22,8 \%$ di pedesaan serta $18,4 \%$ laki-laki dan $23,9 \%$ perempuan. Berdasarkan kelompok umur, penderita anemia berumur 5-14 tahun sebesar 26,4\% dan sebesar $18,4 \%$ pada kelompok umur 15-24 tahun.

Status gizi lebih adalah suatu keadaan inflamasi yang bersifat kronis, yang ditandai oleh infiltrasi makrofag kedalam jaringan lemak yang mengalami hipertrofi dan hiperplasi (Yanoff et al., 2007). Keadaan ini memicu terbentuknya sitokin-sitokin proinflamasi salah satunya adalah interleukin-6 (IL-6) (Ganz and Nemeth, 2011; Price dan Schrier, 2010). IL-6 adalah suatu sitokin proinflamasi yang dihasilkan dari jaringan adiposa pada keadaan status gizi lebih. IL-6 akan mempengaruhi kadar hepsidin dalam darah yang akan berpotensial terjadinya gangguan metabolisme besi (McClung and Karl, 2008). Berdasarkan latar belakang di atas maka diperlukan penelitian tentang hubungan asupan protein dan kadar IL-6 dengan kadar hemoglobin pada remaja putri status gizi lebih.

\section{METODE}

Penelitian bersifat observasional analitik dengan desain Cross sectional. Populasi adalah remaja putri SMA kelas X Se Kabupaten Boyolali. Teknik pengambilan sampel dengan cara Multi stage sampling. Pemilihan sekolah secara random terpilih 5 SMA di Kabupaten Boyolali. Sampel dipilih secara quota sebanyak 18-20 remaja putri setiap sekolah. Penelitian dilaksanakan dari tanggal 29-31 Maret 2016 di Kabupaten Boyolali dengan sampel sebanyak 90 remaja putri.

Instrument yang digunakan adalah Timbangan injak, microtoice, kuisioner, alat dan bahan pemeriksaan kadar hemoglobin dengan metode Cyanmethemoglobin, pmeriksaan kadar IL-6 dengan metode ELISA Analisis data secara univariat dan bivariat untuk mengetahui hubungan masing-masing dan keseluruhan variabel bebas dan terikat. Analisis bivariat dengan menggunakan uji korelasi Pearson atau Spearman.

\section{HASIL DAN PEMBAHASAN}

Subjek penelitian adalah remaja putri status gizi lebih usia 15-17 tahun, sebagian besar subjek berusia 16 tahun. Pada tabel 1 terlihat tidak ada perbedaan yang bermakna kadar $\mathrm{Hb}$ pada rentang usia tersebut. Status gizi lebih pada subjek penelitian sebagian besar adalah obesitas dan kadar $\mathrm{Hb}$ yang rendah sebagian besar pada kelompok subjek status gizi obesitas sedangkan kadar $\mathrm{Hb}$ yang normal sebagian besar pada kelompok subjek status gizi overweight (Tabel 1). Lokasi penelitian terbagi menjadi dua, yaitu di dalam dan luar perkotaan. Tabel 1 menunjukkan bahwa kadar $\mathrm{Hb}$ rendah kebanyakan pada remaja putri yang tinggal di dalam perkotaan. Pada sebagian besar subjek penelitian ini mempunyai asupan protein yang baik sampai lebih dan kebanyakan subjek dengan asupan tersebut memiliki kadar $\mathrm{Hb}$ yang rendah. Sebagian besar subjek penelitian mempunyai asupan energi, karbohidrat dan lemak yang kurang dan kebanyakan subjek tersebut mempunyai kadar $\mathrm{Hb}$ yang rendah. Asupan $\mathrm{Fe}$ pada sebagian besar subjek penelitian mempunyai kategori lebih tetapi kadar $\mathrm{Hb}$ pada kelompok tersebut mmiliki kadar $\mathrm{Hb}$ yang rendah (Tabel 1). 
Tabel 1. Karakteristik Subjek Penelitian

\begin{tabular}{|c|c|c|c|}
\hline Karakteristik & $\begin{array}{l}\text { Total } \\
\text { (n) }\end{array}$ & $\begin{array}{c}\text { Kadar } \mathrm{Hb}<12 \mathrm{mg} / \mathrm{dl} \\
\mathrm{n}(\%)\end{array}$ & $\begin{array}{c}\text { Kadar } \mathrm{Hb} \geq 12 \mathrm{mg} / \mathrm{dl} \\
\mathrm{n}(\%)\end{array}$ \\
\hline \multicolumn{4}{|l|}{ Usia } \\
\hline 15 tahun & 12 & $7(7,77)$ & $5(5,55)$ \\
\hline 16 Tahun & 66 & $36(40)$ & $30(33,33)$ \\
\hline 17 Tahun & 12 & $7(7,77)$ & $5(5,55)$ \\
\hline \multicolumn{4}{|l|}{ IMT/ U (Z skor) } \\
\hline Overweight & 11 & $3(3,33)$ & $8(8,88)$ \\
\hline Obesitas & 79 & $47(52,22)$ & $32(35,55)$ \\
\hline \multicolumn{4}{|l|}{ Lokasi } \\
\hline Dalam perkotaan & 54 & $33(36,66)$ & $21(23,33)$ \\
\hline Luar perkotaan & 36 & $17(18,88)$ & $19(21,11)$ \\
\hline \multicolumn{4}{|l|}{ Asupan Protein (gr/hr) } \\
\hline Lebih $(\geq 100 \%$ AKG) & 35 & $20(22,22)$ & $15(16,66)$ \\
\hline Baik (80-90\% AKG) & 14 & $7(7,77)$ & $7(7,77)$ \\
\hline Kurang $(<80 \%$ AKG) & 41 & $23(25,55)$ & $18(19,99)$ \\
\hline \multicolumn{4}{|l|}{ Energi (kkal/hr) } \\
\hline Lebih $(\geq 100 \%$ AKG) & 8 & $5(5,55)$ & $3(3,33)$ \\
\hline Baik (80-90\% AKG) & 8 & $4(4,44)$ & $4(4,44)$ \\
\hline Kurang $(<80 \%$ AKG) & 74 & $40(44,43)$ & $34(37,77)$ \\
\hline \multicolumn{4}{|l|}{ Karbohidrat (gr/hr) } \\
\hline Lebih $(\geq 100 \%$ AKG) & 6 & $4(4,44)$ & $2(2,22)$ \\
\hline Baik (80-90\% AKG) & 14 & $8(8,88)$ & $6(6,66)$ \\
\hline Kurang $(<80 \%$ AKG) & 70 & $37(41,11)$ & $33(36,65)$ \\
\hline \multicolumn{4}{|l|}{ Lemak (gr/hr) } \\
\hline Lebih $(\geq 100 \%$ AKG) & 11 & $7(7,77)$ & $4(4,44)$ \\
\hline Baik (80-90\% AKG) & 9 & $5(5,55)$ & $4(4,44)$ \\
\hline Kurang $(<80 \%$ AKG) & 70 & $37(41,11)$ & $33(36,65)$ \\
\hline \multicolumn{4}{|l|}{$\mathrm{Fe}(\mathrm{mg} / \mathrm{hr})$} \\
\hline Lebih $(\geq 100 \%$ AKG) & 76 & $43(47,77)$ & $33(36,66)$ \\
\hline Baik (80-90\% AKG) & 7 & $4(4,44)$ & $3(3,33)$ \\
\hline Kurang $(<80 \%$ AKG) & 7 & $3(3,33)$ & $4(4,44)$ \\
\hline
\end{tabular}

Subjek penelitian adalah remaja putri status gizi lebih usia 15-17 tahun, sebagian besar subjek berusia 16 tahun. Pada tabel 1.3 terlihat tidak ada perbedaan yang bermakna kadar $\mathrm{Hb}$ pada rentang usia tersebut. Status gizi lebih pada subjek penelitian sebagian besar adalah obesitas dan kadar $\mathrm{Hb}$ yang rendah sebagian besar pada kelompok subjek status gizi obesitas sedangkan kadar $\mathrm{Hb}$ yang normal sebagian besar pada kelompok subjek status gizi overweight (Tabel 1). Lokasi penelitian terbagi menjadi dua, yaitu di dalam dan luar perkotaan. Tabel 1 menunjukkan bahwa kadar $\mathrm{Hb}$ rendah kebanyakan pada remaja putri yang tinggal di dalam perkotaan. Pada sebagian besar subjek penelitian ini mempunyai asupan protein yang baik sampai lebih dan kebanyakan subjek dengan asupan tersebut memiliki kadar $\mathrm{Hb}$ yang rendah. Sebagian besar subjek penelitian mempunyai asupan energi, karbohidrat dan lemak yang kurang dan kebanyakan subjek tersebut mempunyai kadar $\mathrm{Hb}$ yang rendah. Asupan Fe pada sebagian besar subjek penelitian mempunyai kategori lebih tetapi kadar $\mathrm{Hb}$ pada kelompok tersebut mmiliki kadar $\mathrm{Hb}$ yang rendah (Tabel 1).

Asupan protein, energi, karbohidrat, lemak, $\mathrm{Fe}$ dan kadar $\mathrm{Hb}$, dapat dilihat pada Tabel 2. 
Tabel. 2 Asupan Protein, Energi, Karbohidrat, Lemak, Fe dan Kadar Hb

\begin{tabular}{lcccc}
\hline Variabel & n & Min & Maks & Rerata \pm SD \\
\hline Asupan Protein (gr/hari) & & & & \\
Total & 90 & 28 & 132,9 & $50,45 \pm 18,04$ \\
Hewani & 90 & 21 & 99,67 & $37,84 \pm 13,53$ \\
Nabati & 90 & 7 & 33,22 & $12,61 \pm 4,51$ \\
Asupan Energi (kkal/hari) & 90 & 519,7 & 2539,8 & $1339,27 \pm 412,62$ \\
Asupan Karbohidrat (gr/hari) & 90 & 5,3 & 298,2 & $152,62 \pm 76,05$ \\
Asupan Lemak (gr/hari) & 90 & 5,3 & 242,9 & $58,50 \pm 37,47$ \\
Asupan Fe (mg/hari) & 90 & 11,9 & 79 & $40,43 \pm 15,94$ \\
Kadar Hb (mg/dl) & 90 & 7,3 & 15,7 & $12,08 \pm 1,59$ \\
\hline
\end{tabular}

Tabel 3. Asupan Protein, Energi, Karbohidrat, Lemak dan Fe Berdasarkan AKG

\begin{tabular}{lcccc}
\hline \multicolumn{1}{c}{ Asupan } & Rerata \pm SD & AKG & \% AKG & Ket \\
\hline Protein (gr/hari) & $50,45 \pm 18,04$ & 59 & 85,50 & Baik \\
Energi (gr/hari) & $1339,27 \pm 412,62$ & 2125 & 63,02 & Kurang \\
Karbohidrat (gr/hari) & $152,62 \pm 76,05$ & 292 & 52,26 & Kurang \\
Lemak (gr/hari) & $58,50 \pm 37,47$ & 71 & 82,39 & Baik \\
Fe (mg/hari) & $40,43 \pm 15,94$ & 26 & 155,5 & Lebih \\
\hline
\end{tabular}

Tabel. 4 Hasil Uji Korelasi Antara Asupan Protein Total, Protein Hewani, Protein Nabati Dengan Kadar Hb

\begin{tabular}{lcc}
\hline \multirow{2}{*}{ Hubungan } & \multicolumn{2}{c}{ Kadar $\mathbf{H b}$} \\
\cline { 2 - 3 } & Koefisien korelasi & $\mathbf{p}$ \\
\hline Asupan protein total dan kadar $\mathrm{Hb}$ & 1,00 & 0,132 \\
Asupan protein hewani dan kadar $\mathrm{Hb}$ & 1,00 & 0,134 \\
Asupan protein nabati dan kadar $\mathrm{Hb}$ & 1,00 & 0,134 \\
\hline
\end{tabular}

Asupan makanan pada subjek penelitian meliputi asupan protein, energi, karbohidrat, lemak dan Fe. Asupan makanan tersebut memiliki variasi yang sangat besar pada seluruh subjek penelitian, hal tersebut terlihat dari beda kadar minimal dan maksimal masing-masing asupan yang terlalu besar serta standar deviasi masingmasing asupan $\pm 30-60 \%$ dari rerata asupan pada keseluruhan

subjek penelitian (Tabel 2). Kadar $\mathrm{Hb}$ pada seluruh subjek penelitian memiliki kadar minimal yang sangat rendah dan kadar maksimal yang terlalu tinggi sehingga rerata kadar $\mathrm{Hb}$ subjek penelitian memiliki kadar normal (Tabel 2)

Asupan protein, energi, karbohidrat, lemak dan Fe pada remaja putri dengan status gizi lebih dengan angka kecukupan gizi dapat dilihat pada Tabel 3.

Asupan makanan dalam tubuh akan digunakan sebagai sumber energi, sumber energi utama dalam tubuh adalah dari asupan energi dan karbohidrat, jika asupan kedua sumber makanan tersebut kurang maka sumber energi diambil dari asupan lemak, jika asupan lemak tidak mencukupi maka kebutuhan energi dari asupan protein. Subjek penelitian adalah remaja putri status gizi lebih, berdasarkan

AKG rerata asupan energi dan karbohidrat dalam kategori kurang, rerata asupan protein dan lemak dalam kategori baik dan rerata asupan $\mathrm{Fe}$ dalam kategori lebih (Tabel 3).

Hasil uji korelasi dengan uji Rank Spearman dapat dilihat pada Tabel 4.

Hemoglobin adalah salah satu kompenen darah yang berfungsi untuk transportasi oksigen dalam darah. Hemoglobin tersusun atas hem (zat besi) dan globin (protein). Asupan protein total, protein hewani dan protein nabati tidak berpengaruh terhadap kadar $\mathrm{Hb}$ pada remaja putri status gizi lebih (Tabel 4).

Analisis hubungan tanda inflamasi dengan kadar $\mathrm{Hb}$ adalah dengan menganalisis kadar IL-6 dengan kadar $\mathrm{Hb}$ pada subjek dengan status gizi lebih. Total analisis hubungan kadar IL-6 dan kadar $\mathrm{Hb}$ dilakukan pada 40 subjek, hal tersebut berdasarkan rumus minimal sampel penelitian ini 
adalah 33 subjek, sedangkan kapasitas kid IL-6 untuk pemeriksaan kadar IL-6 dua kali adalah 40 subjek. Hasil pemeriksaan kadar IL-6 dengan pemeriksaan elisa terdapat 18 sampel yang kadarnya melebihi standar pada elisa kid sehingga hanya 22 subjek penelitian yang dapat dianalisis untuk hubungan kadar IL-6 dengan kadar $\mathrm{Hb}$. Hasil analisis 22 subjek tersebut dapat dilihat pada tabel 5:

Tabel 5. Hasil Analisis Kadar IL-6 Dan Kadar Hb

\begin{tabular}{lcccc}
\hline \multicolumn{1}{c}{ Variabel } & n & Min & Maks & Rerata \pm SD \\
\hline Kadar & & & & \\
$\mathrm{IL}-6(\mathrm{ng} / \mathrm{dl})$ & 22 & 0,03 & 0,45 & $0,25 \pm 0,15$ \\
$\mathrm{Hb}(\mathrm{mg} / \mathrm{dl})$ & 22 & 7,30 & 11,90 & $10,78 \pm 1,13$ \\
\hline
\end{tabular}

IL-6 adalah salah satu sitokin proinflamasi yang diproduksi pada kondisi inflamasi kronis seperti keadaan status gizi lebih. Peningkatan kadar IL-6 akan berakibat terhadap kadar $\mathrm{Hb}$ pada keadaan status gizi lebih. Rerata kadar $\mathrm{Hb}$ pada subjek penelitian ini dikategorikan dalam kadar $\mathrm{Hb}$ yang rendah (Tabel 5).
Analisis ini bertujuan untuk mengetahui hubungan kadar IL-6 dengan kadar $\mathrm{Hb}$ pada 22 subjek. Uji korelasi antara kadar IL-6 dengan kadar $\mathrm{Hb}$ menggunakan uji Pearson Product Moment dalam menganalisis data penelitian ini.

Tabel. 6 Hasil Uji Korelasi Antara Kadar IL-6 Dengan Kadar Hb

\begin{tabular}{ccc}
\hline \multirow{2}{*}{ Hubungan } & \multicolumn{2}{c}{ Kadar Hb } \\
\cline { 2 - 3 } & Koefisien korelasi & $\mathbf{p}$ \\
\hline Kadar IL-6 dengan kadar $\mathrm{Hb}$ & 0,116 & 0,607 \\
\hline
\end{tabular}

IL-6 merupakan salah satu sitokin proinflamasi yang berperan dalam proses pembentukan hemoglobin. Kadar IL-6 tidak berhubungan dengan kadar $\mathrm{Hb}$ pada remaja putri dengan status gizi lebih (Tabel 6).

Berdasarkan hasil penelitian yang telah disajikan, dapat diketahui bahwa remaja putri status gizi lebih umumnya berusia 16 tahun. Lebih dari $80 \%$ remaja putri status gizi lebih adalah dalam kategori obesitas (berdasarkan Zskor $\mathrm{IMT} / \mathrm{U}>2 \mathrm{SD}$ ). Sebagian besar remaja putri status gizi lebih tinggal di wilayah perkotaan. Jumlah remaja putri status gizi lebih dengan kadar $\mathrm{Hb}$ $<12 \mathrm{mg} / \mathrm{dl}$ dan $\geq 12 \mathrm{mg} / \mathrm{dl}$ tidak jauh berbeda yaitu $55,55 \%$ dan $44,45 \%$. Hasil penelitian menunjukkan asupan $\mathrm{Fe}$ remaja putri status gizi lebih dalam kategori lebih ( $>100 \%$ AKG), asupan protein dan lemak dalam kategori baik $(80-90 \%$ AKG) dan asupan energi dan karbohidrat dalam kategori kurang $(<80 \% \mathrm{AKG})$. Hasil uji bivariat menunjukkan bahwa asupan protein tidak ada korelasi dengan kadar $\mathrm{Hb}$ pada remaja putri status gizi lebih dengan $\mathrm{p}$ value 0,132 . Kadar IL-6 tidak ada korelasi dengan kadar $\mathrm{Hb}$ pada remaja putri status gizi lebih $\mathrm{p}$ value 0,607 .

\section{Karakteristik Subjek Penelitian}

Subjek penelitian sebagian besar berusia 16 tahun $(73,33 \%)$, hal ini sesuai dengan program pemerintah ditetapkan usia masuk Sekolah Dasar adalah 7 tahun, sehingga saat masuk sekolah menengah atas (kelas X) berusia 16 tahun. Status gizi lebih pada remaja putri dalam penelitian ini meliputi overwight dan obesitas. Kadar $\mathrm{Hb}$ pada subjek penelitian ini tidak jauh berbeda antara status gisi overweight dan obesitas. Hal ini sesuai dengan penelitian sebelumnya yang menyebutkan bahwa tidak ada hubungan yang bermakna antara staus gizi dengan kadar $\mathrm{Hb}$ pada remaja putri (Kevin et al., 2015; Indartanti dan Kartini, 2014; Salam, 2012).

Status gizi subjek penelitian sebagian besar adalah obesitas dan domisili dalam perkotaan, hal ini dimungkinkan remaja putri yang tinggal di dalam perkotaan lebih mudah mengakses berbagai makanan lezat rendah gizi atau makanan cepat saji yang berakibat terhadap kejadian obesitas. Hal ini sejalan dengan penelitian sebelumnya yang menyebutkan bahwa terdapat perbedaan asupan makanan pada remaja yang tinggal di dalam perkotaan dan di luar perkotaan (Mahdiah, 2015; 
Wiwied et al. 2012; Dwiningsih dan Pramono, 2011; Rudy, 2007). Tempat tinggal secara tidak langsung berpengaruh terhadap kejadian status gizi lebih pada remaja, karena di dalam perkotaan akses, distribusi dan pemilihan makanan lebih banyak bila dibandingkan wilayah luar perkotaan. Sehingga tempat tinggal remaja mempengaruhi asupan makan dan pola makanan seorang remaja, apabila asupan makanan tidak seimbang antara makronutrien dan mikronutrien maka akan berakibat terhadap status gizi. Usia remaja merupakan usia tertarik dengan hal-hal baru dan sebagian besar bsangat mudah terpengaruh dengan lingkungan sekitar dan teman sebayanya. (Ratu, 2011; Dasuki, 2002). Asupan makanan pada remaja putri di dalam perkotaan lebih tinggi asupan energi, karbohidrat, lemak dan protein dibandingkan dengan vitamin, mineral dan serat.

Asupan protein pada sebagian besar subjek penelitian adalah dalam kategori baik-lebih. Kadar $\mathrm{Hb}$ yang rendah lebih dominan pada asupan protein baik-lebih. Asupan energi, karbohidrat dan lemak pada subjek penelitian adalah kurang. Kadar $\mathrm{Hb}$ yang rendah mayoritas terjadi pada subjek dengan asupan yang rendah tersebut. Asupan protein tidak mempengaruhi kadar $\mathrm{Hb}$ pada remaja putri status gizi lebih. Penelitian ini juga sejalan dengan penelitian Shanon et al., 2014; Putri 2011; Fernandez dan Indrayani, 2010 bahwa tidak ada hubungan bermakna antara asupan protein dengan kadar $\mathrm{Hb}$. Asupan makanan pada remaja sangat berperan penting dalam proses pertumbuhan dan perkembangan serta pemeliharaan tubuh, karena dalam asupan makanan yang baik tersebut mengandung makanan sumber energi, sumber zat pengembang, sumber zat pembangun dan sumber zat pengatur (Sjarif et al., 2011; Sulistyoningsih, 2011; Almatsier et al., 2011; Toschke et al., 2005). Sumber energi, sumber zat pengembang, sumber zat pembangun dan sumber zat pengatur adalah energi, karbohidrat, lemak dan protein. Dalam penelitian ini asupan energi, karbohidrat $\mathrm{n}$ lemak dalam kategori kurang sehingga protein sebagai sumber energi, sumber zat pengembang, sumber zat pembangun dan sumber zat pengatur. Asupan energi, karbohidrat, lemak dan protein pada remaja status gizi lebih digunakan untuk memenuhi kebutuhan energi dan tidak berperan dalam proses pembentukan hemoglobin, sehingga kadar hemoglobin mayoritas adalah rendah.
Ketersediaan protein dan Fe dalam tubuh sangat tergantung dari asupan zat gizi tersebut. $\mathrm{Fe}$ adalah kompenen pembentuk hem dan protein adalah kompenen utama globin. $\mathrm{Fe}$ terbagi menjadi dua golongan, yaitu $\mathrm{Fe}$ hem dan $\mathrm{Fe}$ nonhem, Fe hem berasal dari sumber makanan hewani (daging, ikan dan unggas) dan mempunyai sifat mudah diserap oleh tubuh, $\mathrm{Fe}$ nonhem berasal dari sumber makanan nabati (sayur, buah dan biji-bijian) dan mempunyai sifat tidak mudah diserap oleh tubuh. Protein juga berperan pada absorbsi, transportasi dan penyimpanan Fe (Ditjen Bina Gizi Masyarakat, 2008). Kadar hemoglobin sangat dipengaruhi oleh ketersediaan protein dan $\mathrm{Fe}$ dalam tubuh. Apabila hanya $\mathrm{Fe}$ yang tinggi tetapi asupan protein tidak mencukupi maka kadar hemoglobin juga akan rendah. Asupan protein rendah oleh karena pada remaja status gizi lebih ini terjadi kekurangan asupan energi, karbohidrat dan lemak sebagai sumber energi sehingga sumber energi dari protein.

\section{Hubungan Asupan Protein dengan Kadar Hb}

Kadar $\mathrm{Hb}$ pada remaja putri status gizi lebih tidak terpengaruh oleh asupan protein. Hal ini serupa dengan penelitian Novitasari (2014), hasil penelitian yang dilakukan pada 69 remaja putri tidak terdapat hubungan yang signifikan antara asupan protein dan kadar hemoglobin. Penelitian ini juga sejalan dengan penelitian Shanon et al., 2014; Putri 2011; Fernandez dan Indrayani, 2010 bahwa tidak ada hubungan bermakna antara asupan protein dengan kadar $\mathrm{Hb}$. Asupan protein akan digunakan sebagai sumber energi saat asupan energi, karbohidrat dan lemak yang rendah pada remaja putri status gizi lebih. Peningkatan dan penurunan kadar hemoglobin merupakan proses yang kronik (lama), sedangkan asupan makanan yang diambil data nya dalam penelitian ini adalah data asupan sesaat. Sehingga asupan protein tidak berperan pada proses pembentukan hemoglobin pada remaja status gizi lebih.

\section{SIMPULAN}

Berdasarkan hasil penelitian dan pembahasan, maka didapatkan kesimpulan, sebagai berikut: Kadar $\mathrm{Hb}$ pada remaja putri status gizi lebih tidak dipengaruhi oleh asupan protein. Kadar $\mathrm{Hb}$ tidak dipengaruhi oleh kadar IL-6 remaja putri dengan status gizi lebih. 


\section{DAFTAR PUSTAKA}

Almatsier, S., Susirah, S., dan Moesijanti, S. 2011. Gizi Seimbang dalam Daur Kehidupan. Jakarta: PT. Gramedia Pustaka Utama.

Ariyani, R. 2010. Kesehatan Remaja : Problem dan Solusinya. Jakarta : Salemba Medika.

Arisman. 2009. Gizi Daur kehidupan. Jakarta: Penerbit Buku Kedokteran EGC.

Bakta, I.M. 2009. Pendekatan Terhadap Pasien Anemia. Jakarta: Buku Ajar Ilmu Penyakit Dalam. Edisi 5, Jilid II, Pp: 1109-15.

Balitbang Kemenkes RI. 2013. Riset Kesehatan Dasar. Jakarta : Balitbang Kemenkes RI.

Brown, and Judith, E. 2005. Nutrition Thorough the Life Cycle 2ed. USA: Thomson Wadsworth.

Dasuki. 2002. Konsumsi Lemak dan Status Gizi Remaja di Bogor. Fakultas Pertanian Institute Bogor. Bogor.

De Onis, M., Bloosner, M., dan Borghi, E. 2010. Global prevalence and trends of overweight and obesity among preschool children. American Journal of Clinical Nutrition. Vol.92: 1257-64.

Dwiningsih dan Pramono, A. 2013. Perbedaan Asupan Energi, Protein, Lemak, karbohidrat dan Status Gizi pada Remaja yang Tinggal di Wilayah Perkotaan dan Pedesaan. Skripsi. Program Studi Ilmu Gizi Fakultas kedokteran Universitas Diponegoro.

Fernandez, R., dan Indrayani. 2010. Hubungan Tingkat Asupan Protein, Besi dan Vitamin C dengan Kadar Hemoglobin Siswi Kelas XI SMUN 1 Ngawi. Skripsi. Fakultas Ilmu Kesehatan. Universitas Muhammadiyah Surakarta.

Franks, P.W., Hanson, R.L., Knowler, W.C., Silver, M.L., Benneti., dan Looker H.C. 2010. Childhood obesity, other cardiovasculer risk factor, and premature death. New England Journal Medicine. Vol. 362, Pp: 485-93.

Fretham, S.J.B., Carlos, E.S., dan Georgieff, M.K. 2011. The role of iron in learning and memory. Advance Nutrition. Vol.2, Pp: 112-21.

Ganz, T., dan Nemeth E. 2011. Hepcidin and disorders of iron metabolism. Biochimia Biophysic Acta, vol. 62, Pp:347-360.

Indartanti, D., dan Kartini, A. 2014. Hubungan Status Gizi dengan Kejadian Anemia pada Remaja Putri. Journal of Nutrition College. vol.3, No.2, Pp: 33-39.

Kevin, A.S, Max, F.J.M., dan Rompis, J. 2015. Hubungan Antara Status Gizi dengan kadar Hemoglobin pada Remaja Usia 12-14 tahun. Journal e-Clinic. Fakultas Kedokteran Universitas Sam Ratulangi.

Mahdiah. 2015. Obesitas dan Hubungan Konsumsi fast food dengan Kejadian Obesitas pada Remaja SLTP Kota dan Desa di Daerah Istimewa Yogyakarta. Tesis. Program Studi Ilmu Keshatan Masyarakat. Program Pascasarjana UGM. Yogyakarta.

McClung, J.P., dan Karl, J.P. 2008. Iron Deficiency and Obesity: the contribution of inflamation and diminished iron absorption. Nutrition Review, vol.67, no. 2, Pp: 100-104.

Novitasari, S. 2014. Hubungan Tingkat Asupan Protein, Zat besi, Vitamin C dan Seng dengan Kadar Hemoglobin pada Remaja Putri di SMA batik 1 Surakarta. Karya Tulis Ilmiah. Progdi DIII Gizi Universitas Muhammadiyah Surakara.

Price, E.A., dan Schrier, S.L. 2010. Unexplained Aspects of Anemia of Inflamation, Advances in Hematology. Edition.1. New York: McGraw Hill. Pp: 1-5.

Pudjiadi, dan Solihin. 2005. Ilmu Gizi Klinis pada Anak. Jakarta: Fakultas Kedokteran Universitas Indonesia.

Putri, A.A. 2011. Hubungan Antropometri dan Asupan Gizi dengan Kadar Hb dan Ferritin Remaja Putri. 
Skripsi. Fakultas kedokteran Universitas Diponegoro.

Ratu, A.D.S. 2011. Faktor Risiko Obesitas pada Anak 5-15 tahun di Indonesia. Skripsi. Fakultas Kesehatan Masyarakat. Universitas Indonesia. Pp: 37-43.

Rudy, P. 2007. Besar Risiko Frekuensi Makan, Asupan Energi, Lemak, Serat dan Aktivitas Fisik terhadap Kejadian Obesitas pada Remaja Sekolah Menengah Pertama. Skripsi. Program Studi Ilmu Gizi FK UNDIP.

Salam, B. 2012. Hubungan Status Gizi dengan Kadar Hemoglobin Siswi di SMA Negeri 1 Mojolaban Kabupaten Sukoharjo. Skripsi. Program Studi Gizi. Universitas Muhammadiyah Surakarta.

Shanon, G.M., Alexander, S.L.B., dan Shirley, E.S.K. 2014. Hubungan Antara Asupan Protein dan Zat Besi dengan Kadar Hemoglobin Mahasiswa Program Studi Pendidikan Dokter Angkatan 2013 Fakultas Kedokteran Universitas Sam Ratulangi. Skripsi. Fakultas Kedokteran Universitas Sam Ratulangi Manado.

Sjarif, D.R., Lestari, E.D., Mexitalia, M., dan Nasar, S.S. 2011. Obesitas Anak dan Remaja. Buku Ajar Nutrisi Pediatrik dan Penyakit Metabolik. Jakarta: IDAI, Pp: 230 - 241.

Soetjiningsih. 2007. Tumbuh Kembang Remaja dan Permasalahannya. Cetakan ke-2. Jakarta: Sagung Seto.

Sulistyoningsih, H. 2011. Gizi Untuk Ibu Dan Anak. Yogyakarta : Graha Ilmu.

Toschke, A.M., Kuchenhoff, H., Koletzko, B., dan Von, K.R. 2005. Meal Frequency and Childhood Obesity. Obesity Res. vol. 13, no. 11, Pp: 1932-8.

WHO. 2008. Worldwide Prevalence of Anemia 1993-2005. World Health Organization. -www.who.int/ vmnis/indicators/haemoglobin.pdf- Diakses Desember2015

Wiwied, D.O., Lintang, D.S., M.Zen, R. 2012. Hubungan Kebiasaan Konsumsi Fast Food, Aktivitas Fisisk, Pola Konsumsi, Karakteristik Remaja dan Orang Tua dengan Indeks Masa Tubuh (IMT). Jurnal Kesehatan Masyarakat. Pp: 542-553.

Yanoff, L.B., Manzie, C.M., Denkinger, B., McHugh, T., Sebring, N.G., Remaley, A.T., dan Yanovski, J.A. 2007. Inflamation and iron deficiency in the hypoferremia of obesity. International Journals Obesity (Lond). Vol.31, Pp: 1412-1419. 